\title{
Microparticles obtained by complex coacervation: influence of the type of reticulation and the drying process on the release of the core material
}

\author{
Micropartículas produzidas por coacervação complexa: influência do tipo de \\ reticulação e do processo de secagem na liberação do material de recheio
}

\author{
Izabela Dutra ALVIM², Carlos Raimundo Ferreira GROSSO ${ }^{1 \star}$
}

\begin{abstract}
Microparticles obtained by complex coacervation were crosslinked with glutaraldehyde or with transglutaminase and dried using freeze drying or spray drying. Moist samples presented Encapsulation Efficiency (\%EE) higher than $96 \%$. The mean diameters ranged from $43.7 \pm 3.4$ to $96.4 \pm 10.3 \mu \mathrm{m}$ for moist samples, from $38.1 \pm 5.36$ to $65.2 \pm 16.1 \mu \mathrm{m}$ for dried samples, and from $62.5 \pm 7.5$ to $106.9 \pm 26.1 \mu \mathrm{m}$ for rehydrated microparticles. The integrity of the particles without crosslinking was maintained when freeze drying was used. After spray drying, only crosslinked samples were able to maintain the wall integrity. Microparticles had a round shape and in the case of dried samples rugged walls apparently without cracks were observed. Core distribution inside the particles was multinuclear and homogeneous and core release was evaluated using anhydrous ethanol. Moist particles crosslinked with glutaraldehyde at the concentration of $1.0 \mathrm{mM} . \mathrm{g}^{-1} \mathrm{protein}$ (ptn), were more efficient with respect to the core retention compared to $0.1 \mathrm{mM} \cdot \mathrm{g}^{-1} \mathrm{ptn}$ or those crosslinked with transglutaminase (10 U.g $\left.{ }^{-1} \mathrm{ptn}\right)$. The drying processes had a strong influence on the core release profile reducing the amount released to all dry samples.

Keywords: complex coacervation; transglutaminase; glutaraldehyde; controlled release.
\end{abstract}

\section{Resumo}

Micropartículas produzidas por coacervação complexa foram reticuladas com glutaraldeído ou com transglutaminase e secas por liofilização ou por spray drying. As amostras úmidas apresentaram Eficiência de Encapsulação (\%EE) maior que $96 \%$. Os diâmetros médios variaram de 43,7 $\pm 3,4$ a $96,4 \pm 10,3 \mu \mathrm{m}$ para amostras úmidas, de $38,1 \pm 5,36$ a $65,2 \pm 16,1 \mu \mathrm{m}$ para as amostras desidratadas e de $62,5 \pm 7,5$ a $106,9 \pm 26,1 \mu \mathrm{m}$ para as amostras reidratadas. A integridade das partículas sem reticulação foi mantida quando a liofilização foi utilizada. Após a secagem por spray drying, apenas amostras reticuladas mantiveram a integridade da parede. As micropartículas apresentaram forma esférica e no caso das amostras desidratadas, paredes rugosas aparentemente sem rachaduras foram observadas. A distribuição do recheio nas matrizes foi multinucleada e homogênea e a liberação do material de recheio foi avaliada em etanol anidro. Partículas úmidas reticuladas com glutaraldeído na concentração de $1,0 \mathrm{mM} \cdot \mathrm{g}^{-1}$ de proteína foram mais eficientes na retenção do recheio comparadas a $0,1 \mathrm{mM} \cdot \mathrm{g}^{-1}$ de proteína ou reticuladas com transglutaminase (10 $\mathrm{U}_{\mathrm{g}} \mathrm{g}^{-1}$ de proteína). A secagem influiu fortemente no perfil de liberação do recheio, reduzindo a quantidade liberada para todas as amostras secas.

Palavras-chave: coacervação complexa; transglutaminase; glutaraldeído; liberação controlada.

\section{Introduction}

Microencapsulation is a technology to coat substances with a material that isolates and protects them from the environment. In addition to the protection effect, the controlled release may be obtained (THIES, 1995). Microencapsulation by coacervation has been used by some industrial segments such as pharmaceutical, food, chemical, and cosmetics for the controlled release of several types of cores such as flavors, drugs, and paints with a wide range of applications (SCHMITT et al., 1998; KRUIF; WEINBRECK; VRIES, 2004).

Complex coacervation is mainly used to microencapsulate hydrophobic substances and is based on the interaction among different polymers with opposite charges. This interaction forms insoluble complexes and produces phase separation. The deposition of such complexes around a hydrophobic core creates a barrier, thereby allowing its encapsulation (TOLSTOGUZOV, 1991; SCHMITT et al., 1998). Biopolymers which fit for coacervation, have hydrophilic colloidal properties; solubility in aqueous medium; and adequate charge density and linear chains (VANDERGAER, 1974).

Properties such as mechanical and thermal resistance and permeability/release of the coacervated microparticle wall may be altered by crosslinking using chemical or enzymatic compounds (BURGESS; PONSART, 1998; LAMPRECHT; SHÄFFER; LEHR, 2000; KRUIF; WEINBRECK; VRIES, 2004). Glutaraldehyde is a chemical agent used in protein crosslinking, and promotes covalent binding between amino groups. This type of crosslinking is irreversible and resistant to extreme conditions of $\mathrm{pH}$ and temperature (BEPPU; ARRUDA; SANTANA, 1999;

Recebido para publicação em 26/1/2009

Aceito para publicação em 26/6/2009 (004047)

Departamento de Alimentos e Nutrição, Faculdade de Engenharia de Alimentos, Universidade Estadual de Campinas - UNICAMP, CEP 13083-862, Campinas - SP, Brasil,

E-mail: grosso@fea.unicamp.br

${ }^{2}$ Departamento de Tecnologia de Cereais e Chocolates, Cereal Chocotec, Instituto de Tecnologia de Alimentos - ITAL, CEP 13070-178, Campinas - SP, Brasil

${ }^{*}$ A quem a correspondência deve ser enviada 
MWANGI; OFNER, 2004). However, glutaraldehyde presents high toxicity and this precludes its use in food products (VANDELLI et al., 2001). Transglutaminase is an enzyme that promotes crosslinking among proteins resulting in the formation of intra and intermolecular $\varepsilon$ - $(\gamma$-glutamyl) lysine bonds (MOTOKI; SEGURO, 1998).

Drying coacervated microparticles may extend their shelflife and also extend its usage in dehydrated products (BURGESS; PONSART, 1998). Freeze drying, oven drying, water removal with solvents and drying under room conditions may be used to obtain dehydrated coacervated microparticles. However, most of these methods can cause the disintegration of the wall during drying, which may interfere with the size of the particle and with core release properties (THIES, 1995; BURGESS; PONSART, 1998). Spray drying of microparticles may produce individual particles, but the low physical strength of the wall and the conditions used in this process may limit the use of this method (BURGESS; PONSART, 1998).

The objective of this work was to obtain microparticles by complex coacervation using a mixture of paprika oleoresin and soybean oil as core crosslinked with glutaraldehyde or transglutaminase, freeze dried, or spray dried, and then to evaluate the crosslinking and drying effects on the morphological characteristics, microparticle size, and on the release of the hydrophobic core.

\section{Material and methods}

\subsection{Material}

The following materials were used: bovine type B gelatin (bloom $=270 \mathrm{~g}, 88.9 \%$ of protein) donated by Gelita South America (São Paulo, Brazil), gum Arabic (batch 30841, Synth, São Paulo, Brazil), soybean oil Liza, paprika oleoresin Citromax (Garulhos, São Paulo, Brazil), anhydrous ethanol (99\%, Chemco, São Paulo, Brazil), glutaraldehyde (25\% v/v, Nuclear, São Paulo, Brazil), transglutaminase of microbial origin donated by Ajinomoto (Activa TG-S $S^{\otimes}$, São Paulo, Brazil), with activity of $100{\mathrm{U} . \mathrm{g}^{-1}}$ solid, as informed by the manufacturer.

\subsection{Encapsulation procedure}

Coacervated microparticles were produced according to Thies (1995) and Lamprecht, Shäfer and Lehr (2000), with modifications. A mixture of paprika oleoresin and soybean oil $(1: 1), 5 \mathrm{~g}$, was emulsified with $100 \mathrm{~mL}$ of gelatin solution $(2.5 \%$ $\mathrm{w} / \mathrm{w}, 45 \pm 3^{\circ} \mathrm{C}$ ) using an Ultra-Turrax homogenizer (T18, Ika, Germany), 14,000 rpm for 3 minutes. This emulsion was added to $100 \mathrm{~mL}$ of gum Arabic $\left(2.5 \% \mathrm{w} / \mathrm{w}, 45 \pm 3^{\circ} \mathrm{C}\right)$ and magnetically stirred for 10 minutes. Then, $400 \mathrm{~mL}$ of deionized water was added $\left(45 \pm 3^{\circ} \mathrm{C}\right)$, stirring for 5 minutes. The $\mathrm{pH}$ of the mixture was adjusted to $4.0 \pm 0.1$ by adding hydrochloric acid $(2.7 \mathrm{M})$ and then the particles suspension was slowly cooled to $10^{\circ} \mathrm{C}$. After reaching this temperature, samples were transferred to a refrigerator to complete precipitation and further usage.

\subsection{Crossliking and drying of the coacervated microparticles}

For crosslinking with glutaraldehyde, the concentrations evaluated $\left(0.1\right.$ or $\left.1.0 \mathrm{mM}^{-\mathrm{g}^{-1}} \mathrm{ptn}\right)$ were added to the suspension of coacervated particles and the system was maintained under slow magnetic stirring. For transglutaminase, the amount of enzyme used was $10 \mathrm{U}$ per gram of protein, initially solubilized with deionized water; the $\mathrm{pH}$ was adjusted for 4.0 and added to the particle suspension, maintaining the system under slow stirring. The crosslinking reaction time was 18 hours at room temperature $\left(23 \pm 2{ }^{\circ} \mathrm{C}\right)$. After the reaction period, the moist particles were sieved $(\varnothing 25 \mu \mathrm{m})$ and washed three times with deionized water ( $\mathrm{pH} 4.0)$. A portion of the material (with and without crosslinking) was freeze-dried (501, Edwards, UK); initial temperature: $-40{ }^{\circ} \mathrm{C}$, Pressure: $0.1 \mathrm{mmHg}$, final temperature: $25^{\circ} \mathrm{C} / 2$ hours, total cycle time, 48 hours) and stored in a refrigerator. The second portion of the material (with and without crosslinking) was submitted to spray drying (SD-05, Lab-Plant, UK) as an aqueous suspension of coacervated particles; inlet temperature: $225^{\circ} \mathrm{C}$ and outlet temperature: $125^{\circ} \mathrm{C}$, as determined in preliminary experiments.

\subsection{Characterization of the coacervated microparticles}

\section{Mean diameter and size distribution of the particles}

The mean diameter $(\mu \mathrm{m})$ of the coacervated microparticles, with or without cross-linking, moist or dried, was determined by measuring the diameters of at least 150 particles from the images formed in an optical microscope (Olympus, Japan) and captured using a digital camera controlled by the Global Lab Image program, followed by the analysis of the digitalized photos using the free Scion Image program (www.sciocorp.com). For moist and rehydrated microparticles, the images were captured on water and for dried particles in glycerol.

\section{Morphology}

An optical microscope (eclipse E800, Nikon, Japan) and the Image Pro Plus 4.0 software were used to obtain images from moist particles. For dried particles, Scanning Electron Microscopy (SEM) was used. The samples were fixed in stubs using double-faced copper adhesive tape and coated with a thin layer of gold in a Balzer Sputter (SCD50, Baltec, Liechtensten) for 75 seconds using a current of $400 \mathrm{~mA}$. The samples were subsequently observed (JMS-T300, Jeol, Japan) with voltage acceleration of $10 \mathrm{kV}$.

\section{Encapsulation efficiency}

Encapsulation efficiency (EE\%) was calculated using the following Equation 1:

$\mathrm{EE} \%=\frac{\text { Encapsulated core weight }}{\text { Total core weight }} \times 100$

The encapsulated core weight was determined by the difference between the total core, as weighed initially, and the core weight that was lost throughout processing. Nonencapsulated core residues were carefully removed with 
anhydrous ethanol from the homogenizer rod and from the becker used in processing; next they were transferred to the volumetric flask and quantified by spectrophotometry (DU-70, Beckman, USA) using a standard curve at $452 \mathrm{~nm}$. Determinations were performed in triplicate.

\section{Swelling of the microparticles}

Approximately $50 \mathrm{mg}$ of microparticles were weighed in test tubes by adding $5 \mathrm{~mL}$ of distilled water and stirred slowly for 10 minutes. The diameter variation was observed using an optical microscope after 10 and 30 minutes. Since the diameter size did not show differences, a 10-minute period for rehydration was adopted for all samples.

\section{Release measurements}

Moist or dried microparticle samples, with or without crosslinking, were weighed in lidded glass tubes $(75 \pm 5 \mathrm{mg}$ for moist samples and $18.7 \pm 1.3 \mathrm{mg}$ for dehydrated samples) by adding $50 \mathrm{~mL}$ of anhydrous ethanol. The tubes were covered to avoid the effects of light on oleoresin and placed on a rotary shaker at approximately $30 \mathrm{rpm}$ (model AP22 Phoenix, São Paulo, Brazil), at room temperature. After 15, 30, 60, 90, and 120 minutes the tube content was filtered and the oleoresin was quantified through a standard curve. The release of oleoresin was expressed as a percentage of the released oleoresin determined in the filtrate by the total amount of oleoresin contained in the sample. The moisture content of moist and dried microparticles was determined to allow the quantification of the oleoresin encapsulated (ASSOCIATION..., 2000). Determinations were performed in triplicate.

\section{Statistical analysis}

Mean diameter values, encapsulation, and core release percentages for microparticle samples at 120 minutes were statistically assessed by mean comparisons using the Statistica software (Statsoft, USA), basic statistics module to calculate ANOVA and by applying the Tukey test. The mean differences within the $95 \%$ confidence interval $(\mathrm{p}<0.05)$ were regarded as significant.

\section{Results and discussion}

\subsection{Encapsulation efficiency}

Encapsulation efficiencies obtained in this work ranged from $96.1 \pm 1.7$ to $98.3 \pm 0.3 \%$ (Table 1 ). There was no statistical difference among the values obtained $(\mathrm{p}<0.05)$.

Prata et al. (2008) determined $95 \%$ as the encapsulation efficiency for coacervated moist particles without crosslinking and for those crosslinked with transglutaminase or glutaraldehyde. Encapsulation efficiencies ranging from 80 to $100 \%$ were obtained for microparticles produced by complex coacervation using gelatin and gum Arabic in camphor oil encapsulation when the velocity to produce the emulsion, the concentration of the crosslinking agent, and the crosslinking time were evaluated (CHANG et al., 2006).

\subsection{Mean diameter of moist, dried and rehydrated particles}

The mean diameters of crosslinked and non-crosslinked microparticles are presented in Table 2. The diameters of moist particles ranged between $43.7 \pm 3.4$ to $96.4 \pm 10.3 \mu \mathrm{m}$. A great range of values for coacervated particle mean diameter can be observed and this variation is associated to the process conditions including the conditions for emulsion preparation, cooling rate, and characteristics of the wall and core materials such as surface tension and degree of hydrophobicity. Diameter ranges from 0.96 to $24.56 \mu \mathrm{m}$ (KONG et al., 2008), from 39 to $52 \mu \mathrm{m}$ (PRATA et al., 2008), and from 220 to $680 \mu \mathrm{m}$ (BUILDERS et al., 2008) were obtained before.

As expected, drying reduced the size of the particles and after rehydration and the average size of the microparticles was higher than that of the dried microparticles submitted to the same crosslinking agent, for both drying processes used. When spray drying was used, it was not possible to obtain whole microparticles without crosslinking; therefore their diameter could not be determined.

The effect of the type and amount of the crosslinking agent used can be evaluated when the sizes of moist or rehydrated freeze dried particles are observed (Table 2). Particles crosslinked with transglutaminase or with the low level of glutaraldehyde $\left(0.1 \mathrm{mM} . \mathrm{g}^{-1} \mathrm{ptn}\right)$ showed a larger diameter increase than that of moist or rehydrated freeze dried microparticles without crosslinking.

When the amount of glutaraldehyde was increased (1.0 mM.g $\left.\mathrm{g}^{-1} \mathrm{ptn}\right)$, the effect of the crosslinking was enough to control the swelling intensity. In this case, the size of the particles was smaller, or almost the same, than obtained with moist or rehydrated freeze dried microparticles without crosslinking. This effect was probably due to the increase of the number of crosslinks leading to the strengthening of the walls, thereby controlling the absorption of water and the volume of the microparticles (VANDELLI et al., 2001). However, this behavior was not observed for particles obtained by spray dryer, in which the diameter obtained after swelling was similar, without significant differences $(p<0.05)$, regardless of the crosslinking treatment used. Probably this effect was produced by the additional heat damage to the particle walls as a consequence of the use of spray drying compared to freeze drying process. It

Table 1. Encapsulation Efficiency (EE\%). Moist microparticles containing paprika oleoresin/soybean oil $(1: 1, \mathrm{n}=3)$.

\begin{tabular}{lc}
\hline \multicolumn{1}{c}{ Sample treatment } & $\% \mathrm{EE}$ \\
\hline without crosslinking & $97.3 \pm 0.9^{\mathrm{a}^{*}}$ \\
transglutaminase $\left(10{\left.\mathrm{U} . \mathrm{g}^{-1} \mathrm{ptn}\right)}^{\mathrm{a}}\right)$ & $97.6 \pm 1.6^{\mathrm{a}}$ \\
glutataldehyde $\left(0.1 \mathrm{mM} \cdot \mathrm{g}^{-1} \mathrm{ptn}\right)$ & $98.3 \pm 0.3^{\mathrm{a}}$ \\
glutaraldehyde $\left(1.0 \mathrm{mM} \cdot \mathrm{g}^{-1} \mathrm{ptn}\right)$ & $96.1 \pm 1.7^{\mathrm{a}}$ \\
\hline
\end{tabular}

${ }^{\star}$ Means within the column with same letter are not significant $(\mathrm{p}<0.05)$. 
Table 2. Mean diameter of moist, dried, and rehydrated coacervated microparticles, with and without crosslinking $(\mathrm{n}=3)$.

\begin{tabular}{|c|c|c|c|c|c|}
\hline \multirow[t]{2}{*}{ Samples } & \multirow[t]{2}{*}{ Moist } & \multicolumn{2}{|c|}{ Freeze Drying } & \multicolumn{2}{|c|}{ Spray Drying } \\
\hline & & Dried & Rehydrated & Dried & Rehydrated \\
\hline Without crosslinking & $52.2 \pm 3.8^{\text {b.AB }}$ & $39.1 \pm 3.9^{\text {ab. } B}$ & $65.1 \pm 2.4^{\text {b.A }}$ & $\mathrm{ND}^{*}$ & $\mathrm{ND}^{*}$ \\
\hline Transglutaminase (10 U.g $\left.{ }^{-1} \mathrm{ptn}\right)$ & $96.4 \pm 10.3^{\mathrm{a} . \mathrm{AB}}$ & $56.7 \pm 10.8^{a . B}$ & $106.9 \pm 26.1^{\mathrm{a} . \mathrm{AB}}$ & $58.4 \pm 17.4^{\mathrm{a} . \mathrm{AB}}$ & $90.4 \pm 15.2^{\mathrm{a} \cdot \mathrm{AB}}$ \\
\hline Glutaraldehyde $\left(0.1 \mathrm{mM} \cdot \mathrm{g}^{-1} \mathrm{ptn}\right)$ & $82.2 \pm 11.8^{\mathrm{a} . \mathrm{AB}}$ & $60.2 \pm 2.26^{\mathrm{a} . \mathrm{B}}$ & $101.8 \pm 7.7^{\mathrm{a} . \mathrm{A}}$ & $56.6 \pm 11.7^{\mathrm{a} . \mathrm{B}}$ & $100.3 \pm 23.5^{\text {a.A }}$ \\
\hline Glutaraldehyde (1.0 mM.g $\left.{ }^{-1} \mathrm{ptn}\right)$ & $43.7 \pm 3.4^{\text {b.B }}$ & $38.1 \pm 5.36^{\text {b. } B}$ & $62.5 \pm 7.5^{\text {b.B }}$ & $65.2 \pm 16.1^{\mathrm{a} . \mathrm{B}}$ & $98.0 \pm 17.9^{\text {a.A }}$ \\
\hline
\end{tabular}

is also important to consider that the standard deviation is high in some measures, which indicates a limitation of the method or the number of particles used to evaluate the diameter of the particles.

\subsection{Morphology}

Figure 1 presents the morphology obtained for moist microparticles with and without crosslinking. Microparticles presented round format and varied sizes, reflecting the standard deviations obtained during measurement of the mean diameters. It can be observed that microparticles showed a multinuclear distribution of the core material (Figure 1b and Figure 2) presenting homogeneous core distribution, which characterizes particles as monolithic due to the processing conditions used in this work, which are similar to those found before (GUO; ZHAO, 2008). Size distributions of moist or rehydrated microparticles for all crosslinking and drying treatments were unimodal and close to normal distribution (results not shown).

The freeze drying process maintained the wall integrity for all samples, with or without crosslinking. Particles were spherical, with some deformations associated to the shrinking of the matrix during drying including solid bridges between the particles but without cracks.

Coacervated microparticles without crosslinking did not stand the spray drying process and were destroyed (Figure $3 b$ ), as observed before (BURGESS; PONSART, 1998). Crosslinking with the enzyme and with the smaller concentration of the chemical crosslinker (Figure $3 \mathrm{~d}$ and $\mathrm{f}$ ) promoted a partial resistance of microparticles during drying. Figure 3 shows that the integrity of spray-dried particles was maintained only when the chemical crosslinker at a higher concentration

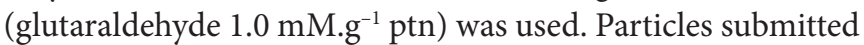
to this treatment presented a round format and a rugged surface that was different from the surface morphology observed for the freeze-dried particles. The rehydration of the dried microparticles was very fast (time $<10$ seconds), and the microparticles returned to their original round format, as presented by the moist particles.

Freeze drying presented a yield that was much higher than the one observed when spray drying process was used. In the latter, large amounts of particles adhered to the drying chamber and the amount of dry sample was very low. Low yield for spraydried gelatin and gum Arabic coacervated particles were also observed before (LAMPRECHT; SHÄFER; LEHR, 2001).

\subsection{Core release}

The scanning of released solutions (standard curve of oleoresin-soybean oil mixture, $\mathrm{R}=0.997, \mathrm{Y}=14.601 \mathrm{X}+0.0024$, where $\mathrm{Y}=$ absorbance and $\mathrm{X}=$ oleoresin concentration in $\mathrm{mg} \cdot \mathrm{mL}^{-1}$ of anhydrous ethanol), in the range of 290 to $700 \mathrm{~nm}$, indicated maximum absorbance at $452 \mathrm{~nm}$. Absorbances ranging between 410 to $510 \mathrm{~nm}$ were associated to carotenoids found in ground paprika and its oleoresins depending on the type of solvent used (HORNERO-MENDEZ; MINGUEZMOSQUERA, 2001; BIACS et al., 1989; RODRIGUEZHUEZO et al., 2004).

Release profiles for paprika oleoresin encapsulated in moist coacervated microparticles without crosslinking or crosslinked with either glutaraldehyde $\left(0.1 \mathrm{mM} \cdot \mathrm{g}^{-1} \mathrm{ptn}\right.$ and $\left.1.0 \mathrm{mM} \cdot \mathrm{g}^{-1} \mathrm{ptn}\right)$ or transglutaminase $\left(10 \mathrm{U}^{-\mathrm{g}^{-1}} \mathrm{ptn}\right)$ in anhydrous ethanol throughout time can be observed in Figure 4.

Moist particles without crosslinking released $100 \%$ of the encapsulated oleoresin after 30 minutes in anhydrous ethanol. As a consequence of the crosslinking effect, it was observed that glutaraldehyde crosslinking at the highest concentration used, was the most efficient to increase the retention of oleoresin inside the particles. The release of $65.6 \%$ of oleoresin after 120 minutes in anhydrous ethanol was observed. However, positive effects although less intense, were also observed in the release of encapsulated oleoresin in particles crosslinked with glutaraldehyde at a lower concentration $\left(0.1 \mathrm{mM}^{-\mathrm{g}^{-1}} \mathrm{ptn}\right)$ or crosslinked with transglutaminase $\left(10{\mathrm{U} . \mathrm{g}^{-1}}^{-1} \mathrm{ptn}\right)$ with release values of 89.9 and $93.8 \%$ respectively, after 120 minutes (Figure 4).

Despite the differences observed, release curves (Figure 4) presented two different kinetic behaviors. The first one with an intense initial release known as the burst effect, probably due to the fast release of the core located near or on microparticle surface. Next, the release becomes constant after 60 minutes showing higher controlled release as the amount of glutaraldehyde increased, effect also observed before (IWANAGA et al., 2003; VANDELLI et al., 2001). 


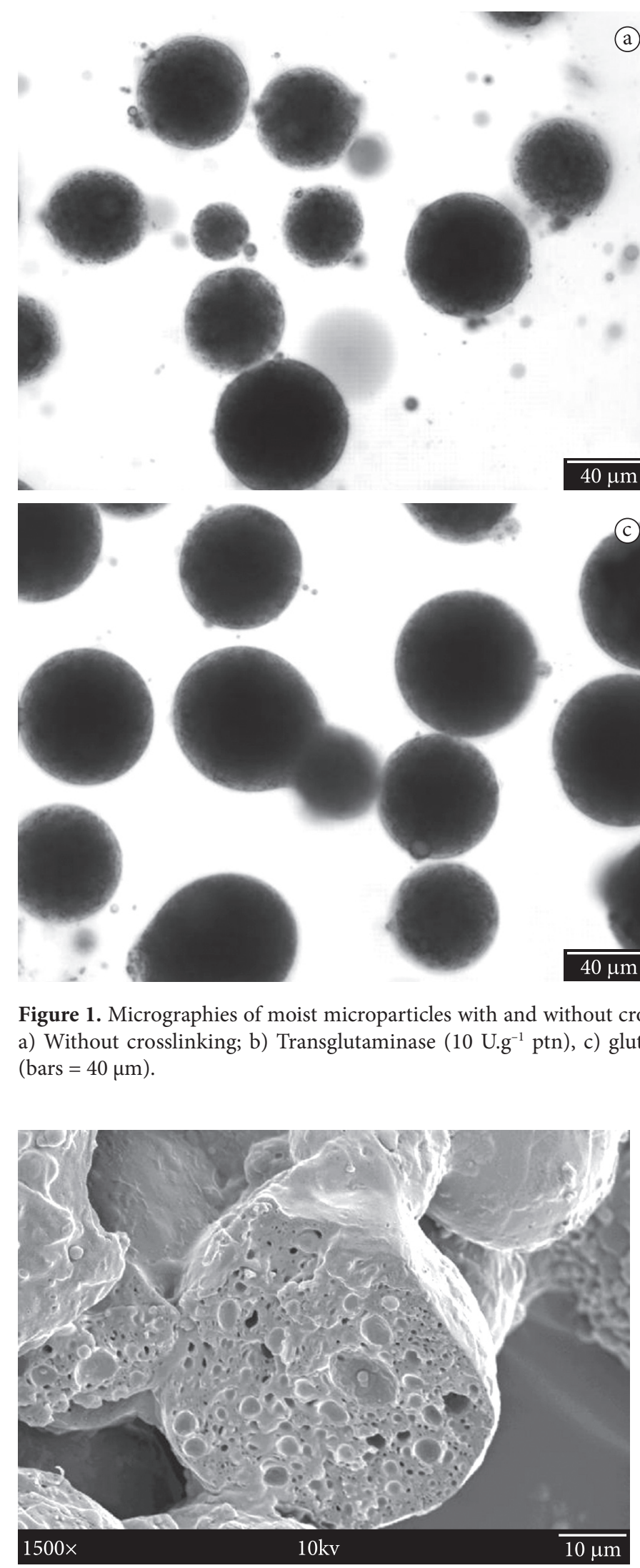
(bars $=40 \mu \mathrm{m}$ ).
Figure 2. Micrography of internal morphology, microparticle dried by spray drying containing paprika oleoresin/soybean oil, crosslinked with glutaraldehyde (1.0 mM.g-1 ptn), scanning electron microscopy (bar $=10 \mu \mathrm{m}$ ).
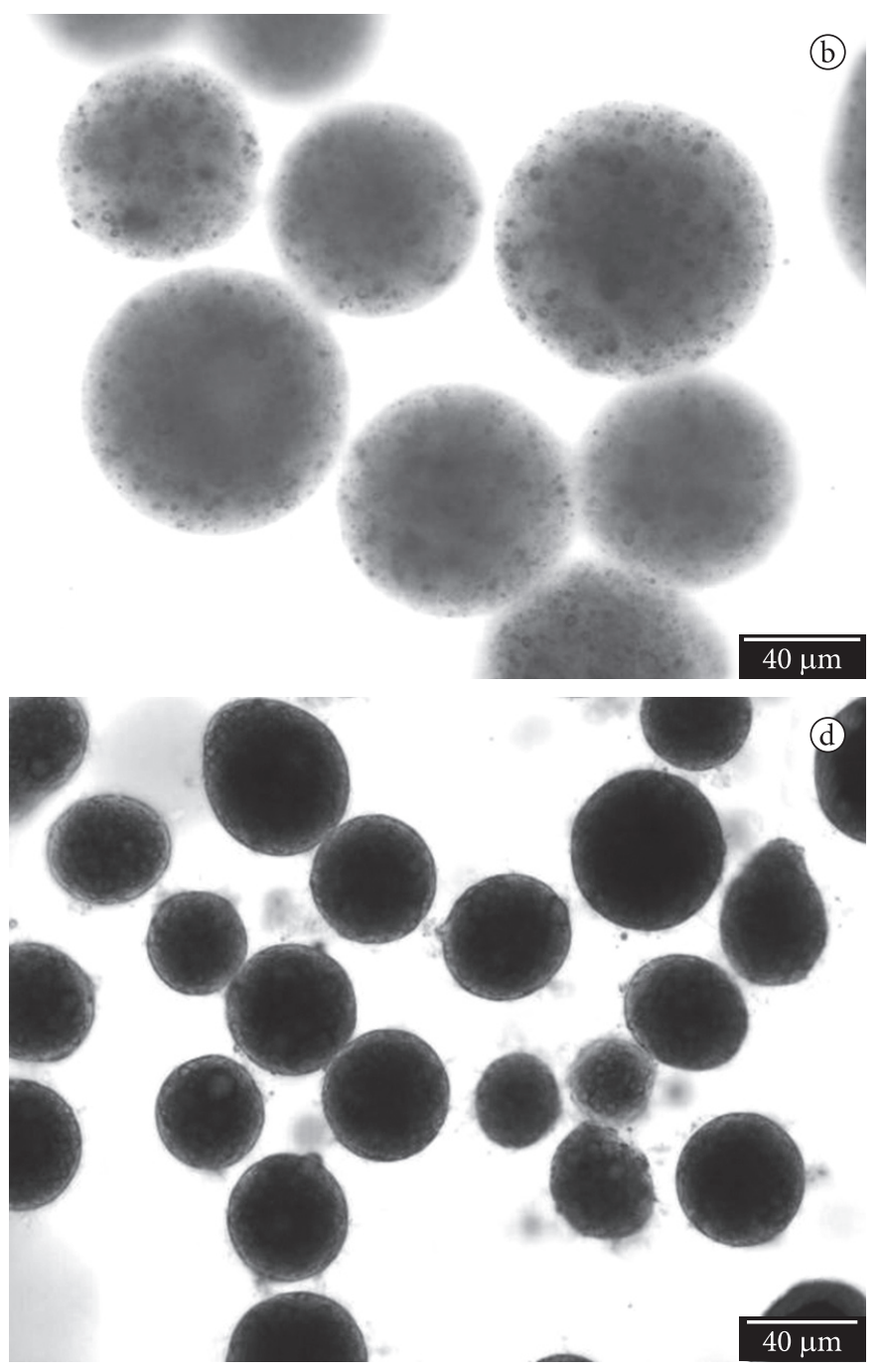

Figure 1. Micrographies of moist microparticles with and without crosslinking containing paprika oleoresin/soybean oil, optical microscopy. a) Without crosslinking; b) Transglutaminase (10 U.g $\left.{ }^{-1} \mathrm{ptn}\right)$, c) glutaraldehyde $\left(0.1 \mathrm{mM} \cdot \mathrm{g}^{-1} \mathrm{ptn}\right)$ and d) glutaraldehyde (1.0 mM.g-1 ptn).

The release of the oleoresin when transglutaminase was used to crosslink the microparticles was close to the release presented by particles without crosslinking $(93.8$ and $100.7 \%$, respectively) indicating that the amount of enzyme used did not interfere significantly with microparticle porosity. Cho, Shim and Park (2003) evaluated the release of fish oil in microparticles with wall made up of soy protein isolate crosslinked with transglutaminase. The release profile for the oil was slow in the first 60 minutes increasing significantly from there until reaching total release after 240 minutes.

De Roos (2003) observed that the water inside the particles obtained by complex coacervation may works as an additional protective layer to retain the hydrophobic core ingredient, usually presenting low water solubility. Overall, this implies in higher core retention in aqueous media. In this study, this protective effect was not observed since the release medium was anhydrous ethanol, which dehydrates moist particles and effectively solubilizes the oleoresin. 

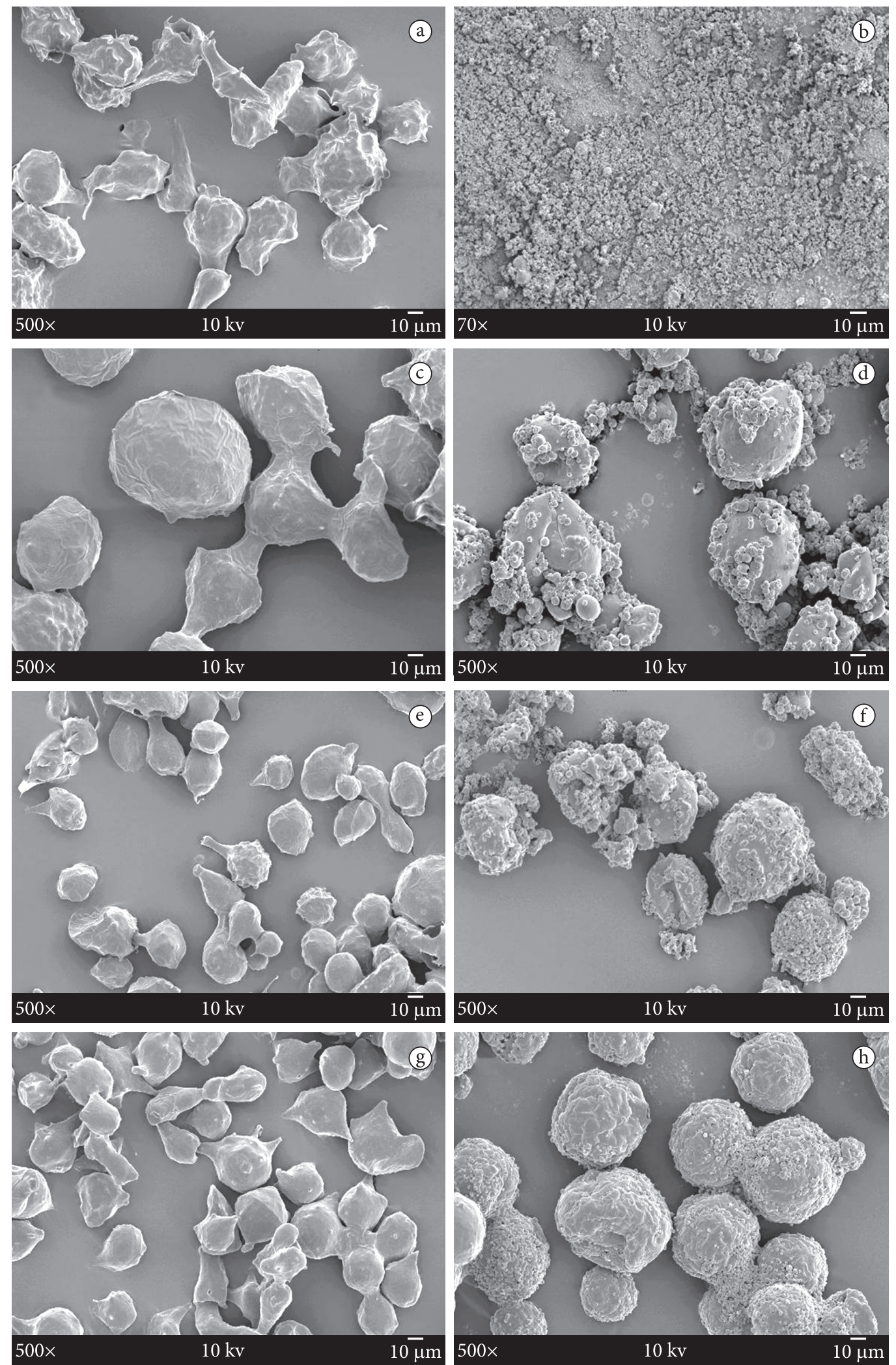

Figure 3. Micrographies of dried microparticles containing paprika oleoresin/soybean oil, scanning electron microscopy: a) and b) without crosslinking; c) and d) transglutaminase (10 U.g $\left.\left.{ }^{-1} \mathrm{ptn}\right), \mathrm{e}\right)$ and f) glutaraldehyde $\left(0.1 \mathrm{mM}^{-g^{-1}} \mathrm{ptn}\right)$ and g) and h) glutaraldehyde $\left(1.0 \mathrm{mM} \cdot \mathrm{g}^{-1} \mathrm{ptn}\right)$. (bars $\left.=100 \mu \mathrm{m}\right)$. Left column: freeze dried microparticles, right column: spray dried microparticles. 


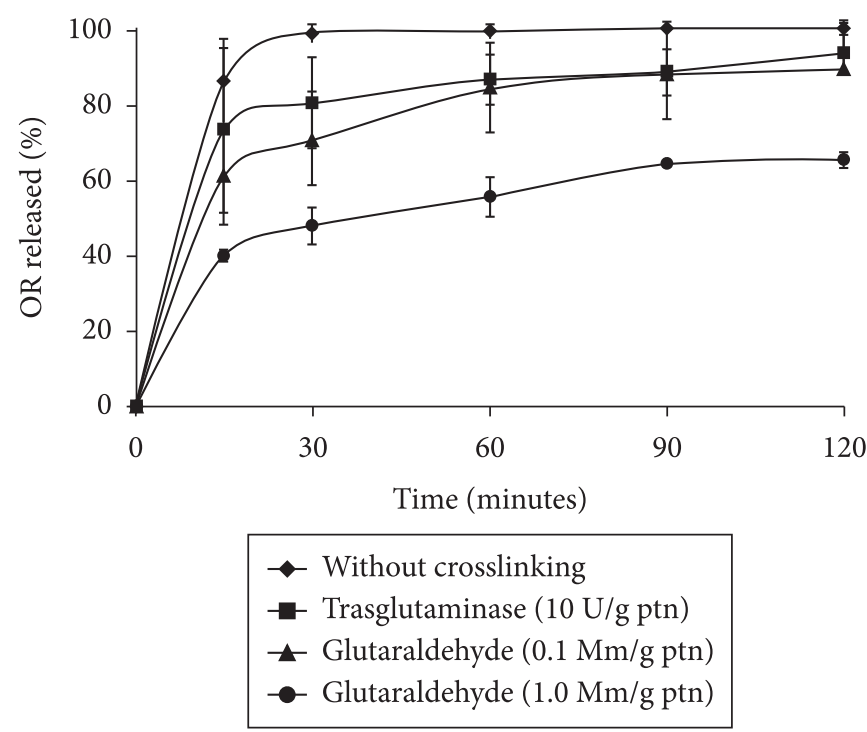

Figure 4. Effect of the crosslinking agent on the core release from moist microparticles: a) without crosslinking, b) Transglutaminase (10 $\left.\left.\mathrm{Ug}^{-1} \mathrm{ptn}\right), \mathrm{c}\right)$ glutaraldehyde $\left(0.1 \mathrm{mM}^{-1} \mathrm{~g}^{-1} \mathrm{ptn}\right)$ and $\left.\mathrm{d}\right)$ glutaraldehyde (1.0 mM.g $\left.\mathrm{g}^{-1} \mathrm{ptn}\right)$. Different low case letters represent statistical differences among samples (with and without crosslinking) for $\mathrm{t}=120$ minutes $(\mathrm{p}<0.05)$.
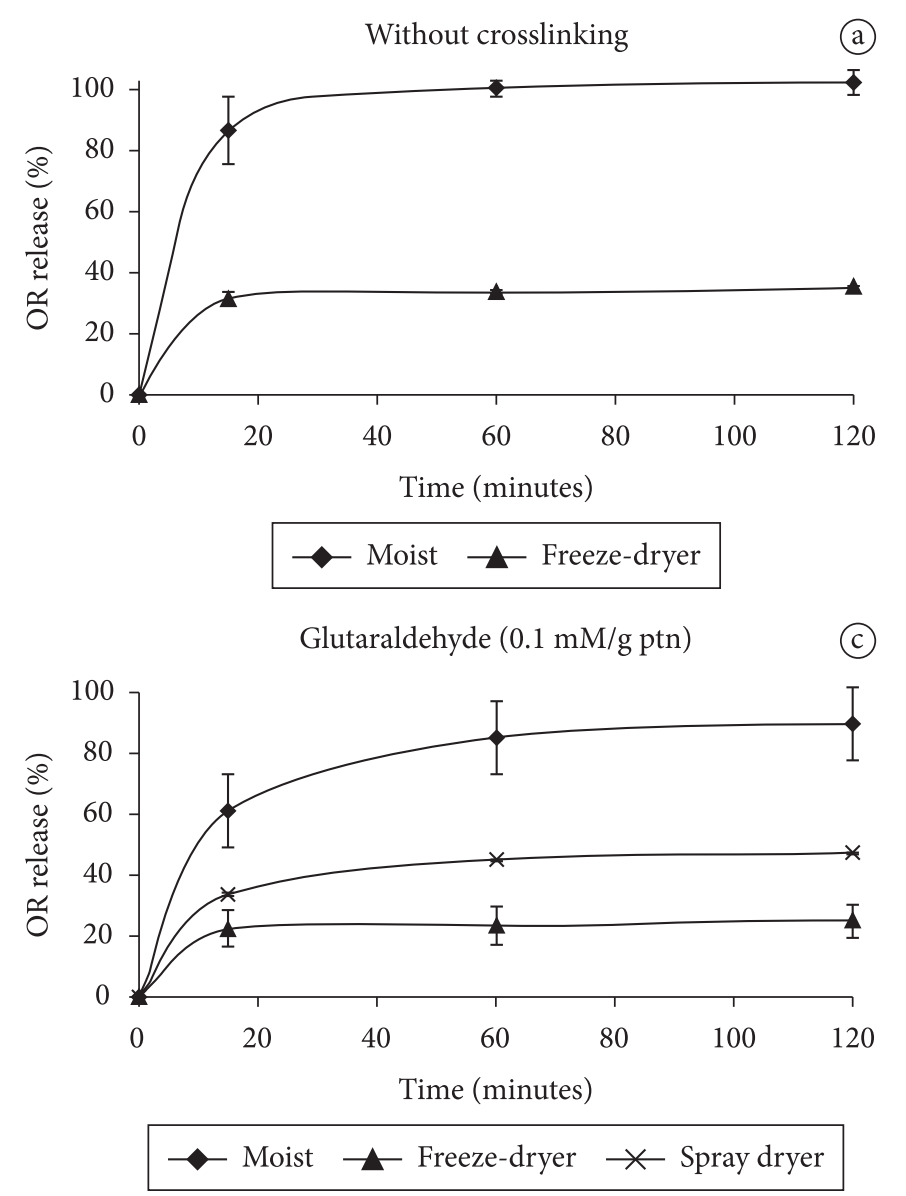

Drying processes, whether or not particles are crosslinked and regardless of the crosslinking agent used, interfered strongly with the encapsulated oleoresin release (Figure 5). Release curves for dry particles were in all cases lower compared to the amount released by moist particles (Figure 4 ). The diameters observed were smaller after drying implying in the shrinkage of the moist particles, which can lead to a reduction in its porosity.

Microparticles crosslinked with transglutaminase or glutaraldehyde at a concentration of $0.1 \mathrm{mM}^{-1} \mathrm{~g}^{-1} \mathrm{ptn}$ (Figure $5 \mathrm{~b}$ and c) after drying using spray dryer released more core material than the respective freeze-dried samples. This high release may be a result of loss of integrity of the particles during drying increasing the solubilization of the core material by anhydrous ethanol. Scanning electron micrographs presented in Figure $3 \mathrm{~d}$ and $\mathrm{f}$ reinforce this behavior showing particles with rugged surfaces. An exception was observed for glutaraldehyde crosslinked particles at the highest concentration (Figures 5d), in which the spray dried sample presented a lower release than the freeze-dried sample for the same crosslinking treatment. This behavior may have been caused by the strong crosslinking effect obtained when glutaraldehyde was used at the highest concentration producing more resistant particles

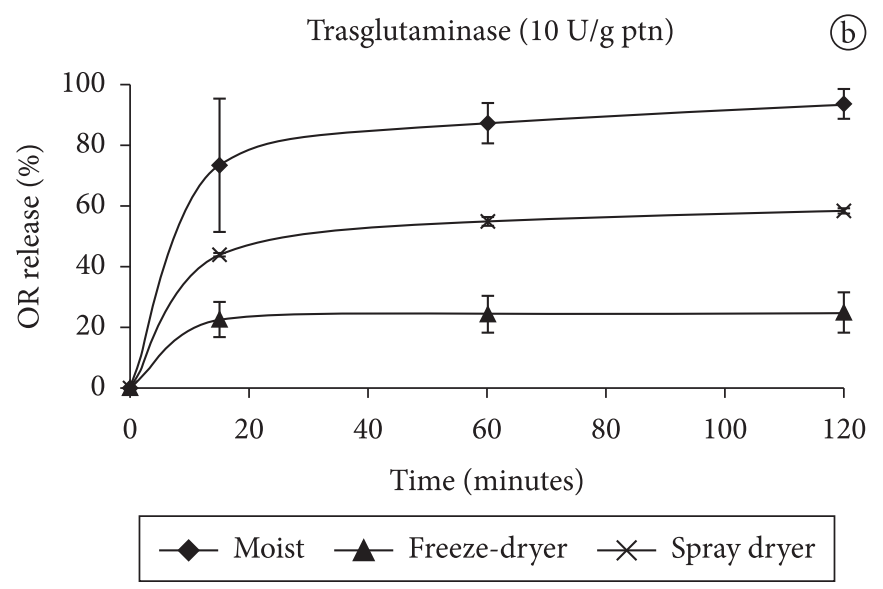

Glutaraldehyde (1.0 mM/g ptn)

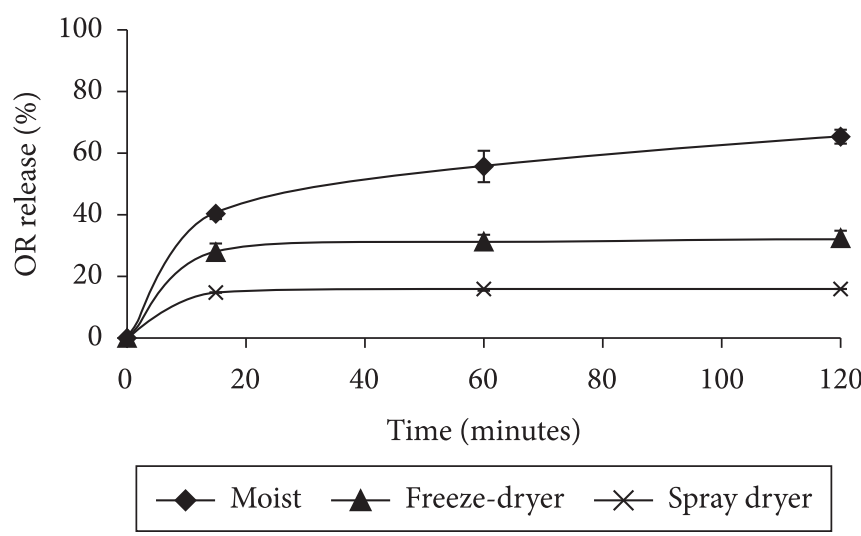

Figure 5. Effect of the drying process on the core release from microparticles: a) moist and freeze dried, without crosslinking; b) moist, freeze dried and spray dried, transglutaminase $\left.\left(10 \mathrm{U}^{-1} \mathrm{ptn}\right), \mathrm{c}\right)$ moist, freeze dried and spray dried, glutaraldehyde $\left(0.1 \mathrm{mM} . \mathrm{g}^{-1} \mathrm{ptn}\right)$ and d) moist, freeze dried and spray dried, glutaraldehyde $\left(1.0 \mathrm{mM} \cdot \mathrm{g}^{-1} \mathrm{ptn}\right)$. 
that would support better the spray drying process. The surface morphologies of these particles (Figure $3 \mathrm{~h}$ ) seem to corroborate the effect observed, with more whole particles produced in spray drying for this treatment.

\section{Conclusions}

The encapsulation of paprika oleoresin by complex coacervation presented high encapsulation efficiency, and the drying of microparticles without crosslinking was possible only when freeze drying was used. Microparticles crosslinked with high amount of glutaraldehyde $\left(1.0 \mathrm{mM} \cdot \mathrm{g}^{-1} \mathrm{ptn}\right)$ were able to maintain the wall integrity after the spray drying process. In this case, rehydration was very fast and the particles recovered their round shape, as presented by moist microparticles. The drying processes seem to have produced a strong effect on particles morphology and on their porosity limiting core release after drying when anhydrous ethanol was used as the solvent. Freeze drying was more efficient than spray drying to dry the microparticles considering the integrity of particles and yield of the processes. Releases of the hydrophobic core for moist samples were differentiated due to crosslinking treatments used with the following release order: particles without crosslinking $>$ glutaraldehyde crosslinked particles $\left(0.1 \mathrm{mM} . \mathrm{g}^{-1} \mathrm{ptn}\right) \sim$ transglutaminase crosslinked particles $>$ glutaraldehyde crosslinked particles $\left(1 \mathrm{mM} \cdot \mathrm{g}^{-1} \mathrm{ptn}\right)$.

\section{Acknowledgments}

The authors are grateful for the financial support provided by FAPESP for the grant of a doctorate fellowship to the first author, which made possible the development of this work.

\section{References}

ASSOCIATION OF OFFICIAL ANALYTICAL CHEMISTS - AOAC. Official methods of analysis of the association of analytical chemists. 17 ed. Geithersburg: AOAC, 2000.

BEPPU, M. M.; ARRUDA, E. J. E; SANTANA, C. C. Síntese e caracterização de estruturas densas e porosas de quitosana. Polímeros, v. 9, p. 163-169, 1999.

BIACS, P. A. et al. Studies on the carotenoid pigments of paprika (capsicum annuum L. var sz-20). Journal Agricultural and Food Chemistry, v. 37, p. 350-353, 1989.

BUILDERS, P. F. et al. Preparation and evaluation of mucinated sodium alginate microparticles for oral delivery of insulin. European Journal of Pharmaceutics and Biopharmaceutics, v. 70, p. 777$783,2008$.

BURGESS, D. J.; PONSART, S. beta-Glucuronidase activity following complex coacervation and spray drying microencapsulation. Journal of Microencapsulation, v. 15, p. 569-579, 1998.

CHANG, C. P. et al. Release properties on gelatin-gum arabic microcapsules containing camphor oil with added polystyrene. Colloid and Surface B: Biointerfaces, v. 50, p. 136-140, 2006.

CHO, Y. H.; SHIM, H. K.; PARK, J. Encapsulation of fish oil by an enzymatic gelation process using tranglutaminase cross-linked proteins. Jounal of Food Science, v. 68, p. 2717-2723, 2003.

DE ROOS, K. B. Effect of texture and microstructure on flavor retention and release. International Dairy Journal, v. 13, p. 593-605, 2003.
GUO, H.; ZHAO, X. Preparation of microcapsules with narrowsize distribution by complex coacervation: effect of sodium dodecyl sulphate concentration and agitation rate. Journal of Microencapsulation, v. 25, n. 4, p. 221-227, 2008.

HORNERO-MENDEZ, D.; MINGUEZ-MOSQUERA, M. I. Rapid spectrophotometric determination of red and yellow isochromic carotenoid fractions in paprika and red pepper oleoresins. Journal Agricultural and Food Chemistry, v. 49, p. 3584-3588, 2001.

IWANAGA, K. et al. Usefulness of microspheres composed of gelatin with various cross-linking density. Journal of Microencapsulation, v. 20, p. 767-776, 2003.

KONG, X. Z. et al. Spreadable dispersion of insect sex pheromone capsules, preparation via complex coacervation and release control of the encapsulated pheromone component molecule. Biomedical Microdevices, v. 11, n. 1, p. 275-285. 2009 . doi 10.1007/s10544008-9234-z.

KRUIF, C. G.; WEINBRECK, F.; VRIES R. Complex coacervation of proteins and anionic polysaccharides. Current Opinion in Colloid \& Interface Science, v. 9, p. 340-349, 2004.

LAMPRECHT, A.; SHÄFER, U. F.; LEHR, C.-M. Characterization of microcapsules by confocal laser scanning microscopy: structure, capsule wall composition and encapsulation rate. European Journal of Pharmaceutics and Biopharmaceutics, v. 49, p. 1-9, 2000.

LAMPRECHT, A.; SHÄFER, U.; LEHR, C.-M. Infuences of process parameters on preparation of microparticle used as a carrier system for $\omega 3$ unsaturated fatty acid ethyl esters used in supplementary nutrition. Journal of Microencapsulation, v. 18, p. 347-357, 2001.

MOTOKI, M.; SEGURO, K. Transglutaminase and its use for food processing. Trends in Food Science \& Technology, v. 9, p. 204-210, 1998.

MWANGI, J. W.; OFNER, C. M. Crosslinked gelatin matrices: release of a random coil macromolecular solute. International Journal of Pharmaceutics, v. 278, p. 319-327, 2004.

PRATA, A. S. et al. Release properties of chemical and enzymatic crosslinked gelatin-gum Arabic microparticles containing a fluorescent probe plus vetiver essential oil. Colloids and Surfaces B: Biointerfaces, v. 67, p. 171-178, 2008.

RODRIGUES-HUEZO, M. E. et al. Microencapsulation by spray drying of multiple emultions containing carotenoids. Jounal of Food Science, v. 69, p. E351-E359, 2004.

SCHMITT, C. et al. Struture and technofuntional properties of proteinpolysaccharide complexes: a review. Critical Reviews in Food Science and Nutrition, v. 38, p. 689-753, 1998.

THIES, C. Complex coacervation. In: THIES, C. (Ed.). How to make Microcapsules - Lecture and Laboratory Manual. Sant Louis, 1995. chap. 5, p. 1-43.

TOLSTOGUSOV, V. B. Functional properties of food proteins and roles of proteins-polisaccharides. Food Hydrocolloids, v. 4, p. 429-468, 1991.

VANDELLI, M. A. et al. Gelatin microspheres crosslinked with D,Lglyceraldehyde as a potential drug delivery system: preparation, characterisation, in vitro and in vivo studies. International Journal of Pharmaceutics, v. 215, p. 175-184, 2001.

VANDERGAER, J. E. Encapsulation by coacervation. In: VANDEGAER, J. E. (Ed.). Microencapsulation: processes and applications. New York: Plenum, 1974. p. 1-20. 